\title{
The Literary Culture of the Renaissance Venetian Empire
}

Erin Maglaque

University of St Andrews

This article examines a corpus of fifteenth-century geographical and epigraphical literature representing the Venetian Mediterranean empire. It was collected and read by Venetian patrician men who were both humanists and part of the political class that governed Venice and its empire. Navigating between literary analysis and history of the book, the article first examines the Venetian legacy of the writings of Cyriac d'Ancona, before investigating the provenance of individual books and their collecting histories. Then, it turns to study the marginalia and annotations in these books by Venetian readers. It suggests that, in its composite construction, this literature provided ways for Venetian readers to imagine their own composite maritime state, particularly its history. Building on recent art historical analysis, I argue that the legitimacy that the aura of antiquity gave to the Venetian imperial enterprise was one of persistence: the Mediterranean empire was a space in which Venetians could encounter a living Greco-Roman imperial past.

Keywords: Renaissance Venice, stato da mar, Mediterranean, geography, cartography, annotation, history of the book

\section{Literary culture and the Venetian empire}

At the centre of this article is a corpus of manuscripts and printed books which were owned, read, collected, and exchanged by Renaissance Venetian men who were both humanists and part of the political class which governed Venice and its maritime empire. ${ }^{1}$

1 The standard work on the Venetian patriciate's involvement in humanist literary culture is Margaret L. King, Venetian Humanism in an Age of Patrician Dominance (Princeton: Princeton University Press, 1987). For a reassessment that broadens the Venetian social 
Often containing both text and image, these books pictured the Venetian Mediterranean world: its ships and sailors, its islands and history, from antiquity to contemporary Venetian rule. The books are sources for a cultural and intellectual history of empire. Part of the literary culture of the political class, they contain the texts, maps, sketches, and inscriptions from which Renaissance Venetian men assembled a set of ideas and expectations about the space and history of their empire.

Here, I examine how the Venetian Mediterranean empire was represented, collected, and read by patrician humanists who were both passionate participants in literary culture, and governors, administrators, and bureaucrats involved in the governance of the empire from the lagoon metropole. Others have begun the still-nascent task of researching the Latin and Greek colonial literatures and artistic cultures of the fifteenth- and sixteenth-century Venetian Mediterranean, from the humanistic centres of manuscript copying and circulation up and down the eastern Adriatic coast, to Cretan humanist-collectors, to Cypriot artistic and architectural histories. ${ }^{2}$ These studies have the exciting potential of being compared within a wider model of cultural relationships between Venice and its subject cities and islands in the Mediterranean, to be examined as an example of the 'empire writing back' to the centre, as first modelled in postcolonial

history of participation in humanism to the 'middling' class of artisans and physicians, see Sarah Gwyneth Ross, Everyday Renaissances: The Quest for Cultural Legitimacy in Venice (Cambridge, Mass.: Harvard University Press, 2016). On the institutional history of the patriciate as officeholders in the stato da mar, see Monique 0'Connell, Men of Empire: Power and Negotiation in Venice's Maritime State (Baltimore: Johns Hopkins University Press, 2009).

2 On Dalmatia, see Luka Špoljarić, 'Power and Subversion in the Ducal Palace: Dalmatian Patrician Humanists and Congratulatory Orations to Newly Elected Doges', in Neo-Latin Contexts in Croatia and Tyrol: Challenges, Prospects, Case Studies, ed. by Neven Jovanović, Johanna Luggin, Luka Špoljarić, and Lav Šubarić (Vienna: Böhlau Verlag, forthcoming). On artistic exchange in this region, Dalmatia and the Mediterranean: Portable Archaeology and the Poetics of Influence, ed. by Alina Payne (Leiden: Brill, 2014). On Cretan literature, see David Holton, 'Classical Antiquity and Cretan Renaissance Poetry', Journal of the Hellenistic Diaspora, 27.1 and 2 (2001), 87-101; idem, Literature and Society in Renaissance Crete (Cambridge: Cambridge University Press, 1991); and Nikolaos M. Panagiotakes, 'The Italian Background of Early Cretan Literature', Dumbarton Oaks Papers, 49 (1995), 281-323. For Cyprus, see Cyprus and the Renaissance (1450-1650), ed. by Benjamin Arbel, Evelien Chayes, and Harald Hendrix (Turnhout: Brepols, 2012). 
literary studies. ${ }^{3}$ But here, I am interested rather in the Venetian literature which took the empire as its subject - in various media, in word and image - and what this literature might tell us about Venetian readers' ideas of governance, difference, and rule in their Mediterranean state.

The primary texts under consideration here are: first, the copies of Cyriacana, or collected extracts from Cyriac d'Ancona's diaries, letters, and miscellanies, that circulated in Venice; second, the Venetian sailor-poet Bartolomeo dalli Sonetti's Isolario, a geographical encyclopaedia of islands printed in Venice in the mid-1480s; and finally, the Florentine geographer Cristoforo Buondelmonti's Liber insularum archipelagi, a manuscript encyclopaedia of islands (I will be concerned here with those individual codices which circulated in Venice and the Veneto). Cyriac d'Ancona (1391-1453/55) was one of the most important figures of the Italian Renaissance to translate the material remains of antiquity into written record, which then was eagerly collected and circulated throughout Italian humanist circles. ${ }^{4}$ Here, I will consider Cyriac's Venetian legacy in particular, and the ways in which his unique approach to antique material culture shaped later Venetian literary engagements with the Aegean world. Bartolomeo dalli Sonetti was a Venetian navigator

\footnotetext{
3 Bill Ashcroft, Gareth Griffiths, and Helen Tiffin, The Empire Writes Back, 2nd edn (London: Routledge, 2002). See Nicholas Davidson, “As Much for its Culture as for its Arms”: The Cultural Relations of Venice and its Dependent Cities, 1400-1700', in Mediterranean Urban Culture, 1400-1700, ed. by Alexander Cowan (Exeter: University of Exeter Press, 2000), pp. 197-214; and for the seventeenth century, Anastasia Stouraiti, 'Collecting the Past: Greek Antiquaries and Archaeological Knowledge in the Venetian Empire', in Re-imagining the Past: Antiquity and Modern Greek Culture, ed. by Dimitris Tziovas (Oxford: Oxford University Press, 2014), pp. 29-46.

${ }^{4}$ Cyriac's texts and letters have been published in E. W. Bodnar, Cyriacus of Ancona and Athens (Brussels: Latomus, 1960); Cyriacus of Ancona's Journeys in the Propontis and the Northern Aegean, 1444-1445, ed. by Edward W. Bodnar and C. Mitchell (Philadelphia: American Philosophical Society, 1976); and, with some overlap with previous editions, Cyriac of Ancona, Later Travels, ed. and trans. by Edward W. Bodnar (Cambridge, Mass: Harvard University Press, 2003). The most comprehensive monograph on Cyriac is Jean Colin, Cyriaque d'Ancône: le voyageur, le marchand, l'humaniste (Paris: Maloine, 1967); and the papers collected in Ciriaco d'Ancona e la cultura antiquaria dell'Umanesimo. Atti del Convegno Internazionale di Studio, ed. by Gianfranco Paci and Sergio Sconocchia (Reggio Emilia: Diabasis, 1998). See also F. Babinger, 'Notes on Cyriac of Ancona and some of his Friends', Journal of the Warburg and Courtauld Institutes, 25.3 (1962), 321-23; Julian Raby, 'Cyriacus of Ancona and the Ottoman Sultan Mehmed II', JWCI, 43 (1980), 242-46.
} 
who wrote geographical poetry and designed island maps under a pseudonym. ${ }^{5}$ His Isolario contains forty-nine woodcut maps of the islands of the Aegean and of the eastern Mediterranean, each facing a sonnet or group of sonnets describing the history, mythology, and topography of the island illustrated. ${ }^{6}$ While Bartolomeo frames his own expertise and experience through Venetian navigation and maritime history, he layers this with classical references, appealing to his humanistically inclined audience and creating a doubled sense of temporality for the Aegean spaces he describes. Finally, Bartolomeo was influenced by an earlier geographical writer and cartographer, the Florentine Cristoforo Buondelmonti. His Liber insularum archipelagi, which circulated in manuscript and entered several collections in Venice, contained Latin descriptions as well as maps of the islands of the Aegean and Mediterranean. ${ }^{7}$

${ }^{5}$ Bartolomeo's name - 'Bartholameus Ioannis Sonetis' - appears on four different lists of potential candidates for the position of homo conseio (chief navigator), two dated 1463, the others 1465 and 1470, in the records of the Collegio in the Venetian State Archives. See Massimo Donattini, 'Bartolomeo dalli Sonetti, il suo Isolario e un viaggio di Giovanni Bembo, 1525-1530', Geografia Antiqua, 3-4 (1994-1995), pp. 211-34 (p. 215). The two registers are held in Venice, Archivio di Stato, Collegio, Notatorio, reg. 10, 84r and v; reg. 11, 76v-77r.

${ }^{6}$ The precise date of the Isolario's printing and the name of the printer are unknown. C. F. Bühler, 'Variants in the First Atlas of the Mediterranean', Gutenberg Jahrbuch, 32 (1957), 94-97. On the isolario as a form: George Tolias, 'Isolarii, Fifteenth to Seventeenth Century', in The History of Cartography, Vol. 3: Cartography in the European Renaissance, ed. by David Woodward (Chicago: University of Chicago Press, 2007), pp. 263-84; and idem, 'The Politics of the Isolario: Maritime Cosmography and Overseas Expansion during the Renaissance', The Historical Review, 9 (2012), 27-52. See also the introduction by Frederick R. Goff to the facsimile edition, Bartolomeo Dalli Sonetti, Isolario. Venice 1485 (Amsterdam: Theatrum Orbis Terrarum, 1972); Frank Lestringant, Le livre des îles: atlas et récits insulaires (Geneva: Droz, 2002); Massimo Donattini, Spazio e modernità: libri, carte, isolari nell'età della scoperte (Bologna: CLUEB, 2000), and idem, 'Bartolomeo dalli Sonetti'.

${ }^{7}$ On Buondelmonti, see H. L. Turner, 'Christopher Buondelmonti and the Isolario', Terrae Incognitae, 19 (1987), 11-28; Giuseppe Ragone, 'Il Liber Insularum Archipelagi di Cristoforo del Buondelmonti: filologia del testo, filologia dell'immagine', in Humanisme et culture geographique à l'epoque du Concile de Constance, ed. by Didier Marcotte (Turnhout: Brepols, 2002), pp. 177-218. The most recent and comprehensive work on Buondelmonti and on the reception of the Liber insularum is Claudia Barsanti, 'Costantinopoli e l'Egeo nei primi decenni del XV secolo. La testimonianza di Cristoforo Buondelmonti', Rivista dell'Istituto Nazionale d'Archeologia e Storia dell'Arte, 56 (2001), 83-254. No definitive edition of the Liber has been published. A facsimile exists of a Latin manuscript copy: Liber 
The article examines these three sources not as fixed texts, but as they circulated in multiple witnesses in both manuscript and print, and in the case of dalli Sonetti's Isolario, in a combination of the two, as readers added their own manuscript notes and illustrations. All told, I consider forty-three individual manuscripts and printed books here, which I argue are evidence of a corpus of Renaissance Venetian literature which took as its primary focus the geography, history, and mythology of the Mediterranean world. These manuscripts and the printed Isolario were produced from the early-fifteenth century until the very early years of the sixteenth century. ${ }^{8}$

Cyriac's writings circulated in manuscript. My article looks in detail at four manuscripts of so-called Cyriacana (collections of Cyriac's own writings combined with copies of his partial transcriptions of books he owned), as well as three copies known to have been owned or commissioned by Venetians. It also looks at an associated manuscript tradition in Venice and the Veneto linked to antiquarian figures such as Giovanni Marcanova and Felice Feliciano. In the case of Cristoforo Buondelmonti, whose Liber insularum circulated particularly in Venice, the article examines six of the sixty-four known manuscript copies published by Hilary Louise Turner. ${ }^{9}$ This text was not printed during the Renaissance. Finally, I have examined twenty-seven printed copies of the Isolario, both in person by visiting collections in the United Kingdom, Italy, and the United States; and digitally, from collections in Germany, France, and Spain. A complete copy census of the Isolario has been published.10 I also discuss three early-sixteenth-century manuscript copies of the Isolario, postdating the printing of the book.

Although these texts and copies were of different genres, formats, and languages, they were each composite, or assembled of heterogeneous texts and images. Throughout

insularum archipelagi: Universitäts- und Landesbibliothek Düsseldorf Ms. G. 13, ed. by Arne Effenberger, Max Plassman, and Fabian Rijkers (Wiesbaden: Reichert, 2005); and a French translation of a Greek manuscript copy: Description des Îles de L'Archipel par Christophe Buondelmonti, ed. by Émile Legrand (Paris: Leroux, 1897).

${ }^{8} \mathrm{On}$ the production of isolarii in this period, see Marziano Guglielminetti, 'Per un sottogenere della letteratura di viaggio: gl'isolari fra Quattro e Cinquecento', in $L a$ letteratura di viaggio dal Medioevo al Rinascimento: generi e problemi, ed. by Silvia Benso (Alessandria: Edizioni dell'Orso, 1989), pp. 107-17.

${ }_{9}^{9}$ Turner, p. 13.

${ }^{10} \mathrm{Goff}$, introduction to the Isolario. 
the article, I consider compositeness both as a central element of Renaissance Venetian literary production, and as part of the hermeneutics of Renaissance reading and writing. I consider how Cyriac d'Ancona, Bartolomeo dalli Sonetti, and Cristoforo Buondelmonti used composite writing in order to create a mosaic of spaces and temporalities in the Mediterranean, and examine how Venetian collectors read these texts at home in their metropolitan studies. ${ }^{11}$ I suggest that compositeness was itself a meaningful literary practice, a dimension of Renaissance textuality fundamental for understanding the ways in which literary culture worked for Venetian readers and writers. This builds upon Arthur Bahr's recent work on compilation 'not [as] an objective quality of either texts or objects, but rather [...] a mode of perceiving such forms so as to disclose an interpretably meaningful arrangement'.12 Bahr argues that late medieval composite manuscripts made meaning that surpassed simply the sum of their parts, arguing for an interpretative relationship between composite forms and the fractured political and literary landscape of his case study, late-medieval London. Importantly, my development of this idea of compositeness extends beyond my three chosen authors and their compilations of geographical and antiquarian material. It also incorporates the layered authorship of the Venetian readers of these texts, who added their own notes, marginalia, and texts to the blank spaces in their manuscripts and printed books.

The composite texts and images indicate how ideas about the space and history of the Venetian Mediterranean were created and exchanged, and even shaped by their authors' experiences in the stato da mar itself.13 Because they were often produced or owned by the humanist patrician men who were governing or administrating the stato da mar, they provide a picture of the Venetian colonial world as it was understood by men

\footnotetext{
11 On the links between literature, geography, and spatiality in books of islands in particular, see Tom Conley, 'Virtual Reality and the Isolario', Annali d'Italianistica, 14 (1996), 121-30.

${ }^{12}$ Arthur Bahr, Fragments and Assemblages: Forming Compilations of Medieval London (Chicago: Chicago University Press, 2013), p. 3.

13 On the relationship between island books and the representation of Venetian sovereignty in the Mediterranean, see Giorgio Mangani, Cartografia morale. Geografia, persuasione, identità (Modena: Panini, 2006); Stouraiti, 'Talk, Script, and Print: the Making of Island Books in Early Modern Venice', Historical Research, 86 (2013), 207-29.
} 
who experienced it: who regularly sailed through the Mediterranean or who governed it from Venice or from Venetian-held cities and islands. ${ }^{14}$ These manuscripts and printed books thus allow us to consider the relationship between knowledge and empire as it unfolded in Venice and the Venetian Mediterranean. Humanists in Venice, as well as the governors who held political offices in the stato da mar, were part of a rich textual culture: one which produced not only documents of administration, but a complex and highly varied literature about empire. Discovering how they created and participated in this literary culture may allow us to perceive some of the ways in which textuality was related to empire in the early modern Mediterranean.

What kind of Mediterranean empire was being elaborated in this corpus of geographical and epigraphical literature? I suggest that this corpus was so widely read, illustrated, and annotated by Renaissance Venetians precisely because it offered readers the imaginative space to work out their ideas and perceptions of their empire and its history retrospectively. Literature and imperial imagination went hand-in-hand, and often looked backwards to the history of Venetian colonization, rather than providing a preformulated ideology for that colonization. This literature organized and made coherent an otherwise composite maritime state, which had formed over the centuries through improvisation and accretion. ${ }^{15}$ Venetian sovereignty was 'archipelagic, episodic and fluid': so too was its representation in geographical literature. ${ }^{16}$

The history of the Venetian empire from the thirteenth century was characterized by an ever-changing constellation of losses and gains. The complex political background which in part gave rise to the constantly changing configuration of the empire across the

\footnotetext{
${ }^{14}$ On Venetian map collecting for domestic display, see Genevieve Carlton, 'Making an Impression: The Display of Maps in Sixteenth-Century Venetian Homes', Imago Mundi, 64.1 (2012), 28-40.

15 The concept of the Venetian empire as composite borrows of course from J. H. Elliott, 'A Europe of Composite Monarchies', Past and Present, 137 (1992), 48-71. Also see Daniel Goffman and Christopher Stroop, 'Empire as Composite: The Ottoman Polity and the Typology of Dominion', in Imperialisms: Historical and Literary Investigations, 1500-1800, ed. by Elizabeth Sauer and Balachandra Rajan (New York: Palgrave, 2004), pp. 129-46.

${ }^{16}$ Stouraiti, 'Talk, Script, and Print', p. 226.
} 
medieval and early modern periods has been well studied by historians. ${ }^{17}$ But of course, it is equally important to consider the motivations of the Venetian colonizers themselves, and the extent to which these guided Venetian expansions and contractions in the Mediterranean. In a recent summary of his extensive research into the Venetian Mediterranean, Benjamin Arbel has examined the Venetians' main motives for expansion, concluding that 'acquisition was not the driving force of Venetian policy'. ${ }^{18}$ Instead, he identifies several circumstances and reasons which were much more contingent and often unpredictable: the voluntary surrender of towns to ensure Venetian protection; acquisitions which ensured the viability of Venetian shipping lanes; acquisitions which served as a kind of 'information network' for the Venetians, allowing them to surveil territories; and territories whose natural resources were particularly important for Venetian trade. ${ }^{19}$ Thus, against the background of complex and competitive economic and political systems in the eastern Mediterranean, Venetian motivations for acquisition and expansion were not driven by an ideology of imperial acquisition. Rather, Venice colonized through a situational and conditional series of expansions and contractions that both shaped and responded to changing political and economic environments.

In their literature, Venetians did not try to tell an 'imperial story', of a logical progression of acquisitions based on an articulated ideology of expansion. For Renaissance Venetians, the legitimacy and authority of their empire - its history — was built upon a perception of doubled time, not linear chronology. As Alexander Nagel and Christopher Wood have provocatively shown, linear chronology was not necessarily 'the inevitable

17 The bibliography is vast. See at least: Byzantines, Latins, and Turks in the Eastern Mediterranean World after 1150, ed. by Jonathan Harris, Catherine Holmes, and Eugenia Russell (Oxford: Oxford University Press, 2012); Quarta Crociata: Venezia, Bizanzio, Impero Latino, ed. by Gherardo Ortalli, Giorgio Ravegnani, and Peter Schreiner (Venice: Istituto Veneto di Scienze, Lettere ed Arti, 2006); Michel Balard and Alain Ducellier, Le partage du monde: échanges et colonisation dans la Méditerranée médiévale (Paris: Publications de la Sorbonne, 1998); État et colonisation au Moyen Âge et à la Renaissance, ed. by Michel Balard (Lyon: La Manufacture, 1989).

18 Benjamin Arbel, 'Venice's Maritime Empire in the Early Modern Period', in A Companion to Venetian History, 1400-1700, ed. Eric R. Dursteler (Leiden: Brill, 2013), pp. 125-253 (p. 137).

19 Ibid., pp. 137-39. 
matrix of experience and cognition' for Renaissance artists and viewers..$^{20}$ Linearity was not the Venetians' experience of empire building, and nor was it the way in which they imagined the history and space of that empire. The legitimacy of antiquity did not necessarily come through the kind of political thought that Thomas Dandelet has recently explored for other early modern European empires, stressing linear progression. ${ }^{21}$ Rather, Venetians had a particularly complicated relationship to the legacy of antiquity. As the metropole of a Mediterranean colony, Venice was particularly well placed as a hub for documenting and assembling collections of Greek and Roman antiquities, even while the metropole itself lacked any material remains of those antique civilizations.

The styling of Venice as a 'new Rome', then, relied on a combination of literary and historiographical efforts on the part of Venetian and Venetian-patronized humanist scholars, and on the importation and circulation of antiquities from Venetian colonies in the Mediterranean, which were rich in classical material culture. ${ }^{22}$ As Patricia Fortini Brown found in her superb study, it was the 'long-standing Venetian capacity for aggregation and incorporation' which was at the heart of their unique cultural affiliation with antiquity. Venice 'absorbed and transcended her models', from ancient Greece to imperial Rome, and even including pharaonic Egypt. ${ }^{23}$ Syncretism was at the core of Venetians' approach to antiquity, and this extended from the city's literature and built environment to its famously self-aggrandizing historical writing and political thought.

More recently, Anastasia Stouraiti has argued that historians must be attentive not only to the reception of classical texts from the Venetian Greek world and their impact on the history of philology, but also to Venetian and Greek engagements with material culture. ${ }^{24}$ Building on this long trajectory of scholarship on Venice's vexed relationship to

\footnotetext{
${ }^{20}$ Alexander Nagel and Christopher S. Wood, Anachronic Renaissance (New York: Zone Books, 2010), p. 9.

21 Thomas Dandelet, The Renaissance of Empire in Early Modern Europe (Cambridge: Cambridge University Press, 2014).

22 D. S. Chambers explores the construction of Venice as a 'New Rome' in The Imperial Age of Venice, 1380-1580 (London: Thames and Hudson, 1970).

23 Patricia Fortini Brown, Venice and Antiquity: The Venetian Sense of the Past (New Haven: Yale University Press, 1996), p. 54.

24 Stouraiti, 'Collecting the Past', p. 31.
} 
antiquity, I want to suggest that the Venetians' imagination of antiquity - as well as their very real encounters with material remains of the past, through texts and their materiality - had an important role in shaping their imagination of the space and history of their own empire. In literature, the legitimacy that the aura of antiquity gave to the Venetian imperial enterprise was one of persistence: the space of the Venetian Mediterranean was one in which Venetian sailors could still encounter a living Greco-Roman imperial past. A composite empire was given a composite literary representation, which evoked authority not despite its compositeness, but because of it: because it most effectively captured the persistence of the classical past into the contemporary Venetian present.

In what follows, I first trace the Venetian legacy of Cyriac d'Ancona, probably the most important writer to translate the physical remains of antiquity in the Aegean world for humanist readers and collectors at home in Italy. The circulation of his work in Venice, with its own complicated relationship to antiquity both in the metropole and in its Mediterranean colonies, proved provocative and foundational. Secondly, I examine the ways in which manuscripts and printed books of Cristoforo Buondelmonti's Liber insularum archipelagi and Bartolommeo dalli Sonetti's Isolario, which represented the geography and physical environment of the Venetian Mediterranean, were collected and circulated amongst the Venetian patriciate. Then, I turn to marginalia recovered in copies of dalli Sonetti's Isolario to provide a case study of how these books were read by their Venetian collectors. Finally, I turn to discuss the composite construction of these books and what this compositeness meant for their readers. I suggest that this composite literary culture, so avidly circulated and collected by Venetian humanists at home, provided a way for these men to imagine their composite maritime state as a whole: a state which had only formed across the centuries haphazardly, through improvisation and contingency. ${ }^{25}$

\section{Translating antiquity: Cyriac d'Ancona}

${ }^{25}$ On the relationship between the history of collecting and the improvisational nature of empire, see Maya Jasanoff, Edge of Empire: Conquest and Collecting on the Eastern Frontiers of Empire, 1750-1850 (London: Fourth Estate, 2005). 
It is impossible to write a history of Venetian literature about the space and antiquity of the Mediterranean world without beginning with Cyriac d'Ancona, perhaps the single most important figure to have translated the physical world of Aegean antiquity into text and image during the Quattrocento. Born in 1391, Cyriac travelled extensively around the Mediterranean world, collecting inscriptions, dealing in books and antiquities, working as a diplomat and merchant, even staying at the Ottoman court of Mehmed II. ${ }^{26}$ As Patricia Fortini Brown notes, Cyriac '[taught] others to look', to understand the material evidence of antiquity as meaningful in its own right and not only as a backdrop for Roman literature. ${ }^{27}$ This teaching took place not only through personal relationships, but primarily through Cyriac's extensive notes of Latin and Greek inscriptions, travel diaries, and geographical descriptions, probably at one point reaching six volumes, known as the Commentaria. They were lost in the Sforza library fire at Pesaro in $1514 .{ }^{28}$ However, Cyriac's miscellaneous collections of inscriptions, notes, and drawings were circulated widely throughout the Renaissance, and Cyriac himself made copies as gifts for important friends. ${ }^{29}$ These excerpts circulated all over the Mediterranean and the Italian diplomatic and humanist world: from Genoese Chios, to Constantinople, to Venice and the Veneto. Cyriac was known in Nicolò Niccoli's Florentine humanist circles: a Vita of Cyriac by his friend Francesco Scalamonti (produced at the insistence of Venetian humanist Lauro Quirini on Crete) records that Cyriac received a dignitary's tour of Niccoli's library and antique coin and sculpture collection. ${ }^{30}$

The wide dispersal and transmission of Cyriac's works on Aegean antiquity meant that they were foundational for many Italian humanists of the Quattrocento. They seem to have been particularly well known in Venice. Several composite manuscripts preserve what is now called 'Cyriacana', collections of inscriptions, drawings, and miscellaneous

\footnotetext{
26 See note 4 above for bibliography on Cyriac.

27 Fortini Brown, Venice and Antiquity, p. 84.

28 Bodnar, Cyriacus of Ancona and Athens, p. 69.

${ }^{29}$ Ibid., pp. 69-70.

30 Francesco Scalamonti, Charles Mitchell, and Edward W. Bodnar, 'Vita Viri Clarissimi et Famosissimi Kyriaci Anconitani', Transactions of the American Philosophical Society, 86.4 (1996), 1-246 (p. 132).
} 
texts that were probably copied and circulated from Cyriac's own manuscript collections. ${ }^{31}$ The popularity of these Cyriacana collections, where Cyriac's drawings and texts were copied alongside books he owned (including the fourth book of Poggio Bracciolini's De Varietate Fortunae which reports Nicolò di Conti's Indian travel account, Pomponius Mela's Cosmographia, and Cristoforo Buondelmonti's Liber insularum archipelagi), indicates the diffusion of the Mediterranean encounter with antiquity through heterogeneous compilations of text, epigraph, and image.

These compilations were particularly popular in Venice and the Veneto amongst elite collectors. Cyriac was in Venice and Padua in 1448, when he presumably made contact with members of humanist circles in the Veneto. ${ }^{32}$ From his early career in Ancona, Cyriac's patron was the Venetian cardinal Gabriel Condulmer, who would eventually become Pope Eugenius IV. ${ }^{33}$ Probably when Cyriac was in the Veneto in the late 1440 s, the Venetian bishop of Padua, Pietro Donato, commissioned a sylloge from Cyriac, the 'Epigramata litteris maiusculis scripta Latina et Greca et us plurimum Romana'. Donato had this bound into his personal miscellany, a manuscript which also included histories of Venice, a copy of the inscription on Petrarch's tomb in nearby Arquà, classical texts such as Frontinus's De aqueductibus urbis Romae, and indices of Greek authors divided by subject. ${ }^{34}$ Donato's better known manuscript, his 1436 commission of a copy of the Codex Spirensis Notitia Dignitatum, includes a depiction of Constantinople that the illuminator Peronet Lamy very likely copied from Cyriac's drawings of the city, provided by Donato himself. ${ }^{35}$ Cyriac's antiquarian work must also have been well known to Venetian humanist Lauro Quirini on

31 Manuscripts of Cyriacana include: Oxford, Bodleian Library, MS Canon. Misc. 280 (see Charles Mitchell, 'Ex libris Kiriaci Anconitani', Italia Medioevale e Umanistica, 5 (1962), 283300); Rome, Biblioteca Casanatense, MS 106, and Treviso, Biblioteca Comunale, MS 323 (see Barsanti, p. 90); and Venier's manuscript held in Berlin (see below, note 47). See also Ruth Barbour, 'A Thucydides Belonging to Cyriac d'Ancona', The Bodleian Library Record, 5 (1954), 9-13; R. Sabbadini, Le scoperte dei codici latini e greci ne' secoli XIV e XV (Florence: Sansoni, 1905), pp. 48-49.

${ }^{32}$ Cyriac, Later Travels, p. xiii.

33 Bodnar, Cyriacus of Ancona and Athens, p. 20.

34 Berlin, Staatsbibliothek, MS Hamilton 254. See Theodor Mommsen, 'Uber die Berliner Excerptenhandschrift des Petrus Donatus,' Jahrbuch der Königlich Preussischen Kunstsammlungen, 4 (1883), 73-89.

35 Bodleian, MS Canon. Misc. 378. 
Crete, who requested from Cyriac an account of his life (eventually provided by Scalamonti, as noted above). Copies of excerpts from Cyriac's Commentaria seem to have circulated particularly in the Veneto. Theodor Mommsen proposed that the so-called 'Antiquum Venetum', a now-lost epigraphical sylloge created by Cyriac for the Venetian Contarini family, was the source for many of these manuscript copies. ${ }^{36}$ This original source is reflected in other Veneto collections, including Giovanni Marcanova's well known copies (Marcanova worked in Padua and Bologna); ${ }^{37}$ and the manuscript owned by the Venetian Alessandro Strozza now in the Biblioteca Laurenziana. ${ }^{38}$ Scalamonti's Vita appears in one manuscript, produced by Veronese antiquary and scribe Felice Feliciano for a Milanese member of the Gonzaga court in Mantua. ${ }^{39}$ This manuscript preserves a copy of Feliciano's Iubilatio, a fanciful account of his idyllic travels around Lake Garda in 1464 with his friends Andrea Mantegna, Samuele da Tradate, and Giovanni Marcanova, gathering inscriptions and searching for antiquities in paradisiacal gardens.

A letter from one Antonio di Leonardo, almost certainly a Venetian, to Felice Feliciano, neatly summarizes Cyriac's Venetian legacy:

[Cyriac] may be considered a man who, among ancients, would have been most ancient: a man well learned in sundry matters, especially in Greek and Latin literature, as his opuscula that are now circulating bear witness: a man, in short, who travelled over almost the whole world. With his own eyes he inspected buildings, temples of the gods, marble statues, inscriptions, and all manners of antiquities. Nor was he ever daunted by the harshness of the way, the cruelty of the sea, or the weariness of long journeying: everything was most easy, agreeable, and pleasant to him on account of his virtue and the antiquities to be discovered. 40

\footnotetext{
${ }^{36}$ Cyriac, Later Travels, p. 123.

37 On Marcanova, see Fortini Brown, pp. 120-26.

38 Florence, Biblioteca Medicea Laurenziana, MS 10, 77. Cyriac, Later Travels, p. 123.

39 'Vita Viri Clarissimi', p. 1.

40 'Habeas quod vir ille inter antiquos antiquissimus fuisset, beneque in variis rebus eruditus, litteris praesertim Graecis atque Latinis; nam opuscula ab eo edita quae vagantur testes sunt de eo qui, ne longius quam statui sim, totum ferma peragravit mundum. Nam aedificia, templa deorum marmorea, statuas, epigrammata, antiquitates omnes hic propriis
} 
In Antonio's account, 'ancientness' is not simply a temporal characteristic, but refers to a mode of engaging with material culture that is diverse or heterogeneous, comprehensive, and virtuous. Cyriac not only encountered the remains of an ancient world, but also pursued this encounter and documented it 'anciently': indeed, more anciently than the ancients themselves who originally produced those material objects.

The idea of virtuous ancientness that Antonio proposes is closely linked to the fragmentary and heterogeneous nature of the material culture which Cyriac encountered in the Mediterranean, and his composite method of recording and documenting buildings, temples, statues, and inscriptions. For Antonio, Cyriac's ancientness lies in the diversity of Cyriac's learning, the way he considered with his own eyes 'antiquitates omnes', and documented each and every kind of antique object in his opuscula. Cyriac's combinatory technique wove together excerpts from classical literature, and the technical language of the portolano (sailing navigational texts), with the humanist geographical encyclopaedia, combining copied inscriptions with sketches, diagrams, and text. ${ }^{41}$ The Mediterranean physical environment was documented, and the resulting material circulated by elite Venetian collectors, in composite forms: as Antonio writes, it was the heterogeneity of this documentation that became characteristically ancient and virtuous, despite having been produced contemporarily. This heterogeneous documentation of antiquity would prove foundational for later geographical writing about the Mediterranean, particularly in Venice.

\section{Collecting the literature of empire}

Before turning to examine the ways in which Venetians read this geographical writing, I will outline the evidence of collection and patterns of circulation of these texts by Venetian

oculis conspectus est; nec huic unquam nocuit itineris asperitas, nec pelagi saevitia neque longae peregrinationis lassitudo; omnia ob virtutem, ob antiquitates inveniendas facillima, suavia, iucundaque fuerent' ('Vita Viri Clarissimi', Latin p. 196, translation p. 4).

${ }^{41}$ Surviving folios of Cyriac's manuscripts are reproduced in Fortini Brown, Venice and Antiquity, pp. 86-91. These composite approaches were imitated in later appropriations of antiquarian geographies: for instance, in one Cyriacana manuscript, Bodleian, MS Canon. Misc. 280, Buondelmonti's Liber insularum archipelagi was copied alongside sketches of Apollo and excerpts from Boccaccio's De mulieribus claris. 
readers and collectors. Here, I examine indications of provenance, and suggest that these books were primarily circulated and collected by Venetian patricians who were often keen participants both in humanist scholarship and in governing the Mediterranean empire. I argue that in their representation of the Mediterranean empire, their collectability and exchange by Venetian patricians who were often both humanists and governors, and their compositeness, these books must be seen as part of a unified literary culture of empire. I examine the geographical literature about the Mediterranean, either produced in Venice itself or readily circulated amongst Venetian readers, focusing in particular on Cristoforo Buondelmonti's Liber insularum archipelagi, and the Venetian Bartolomeo dalli Sonetti and his Isolario.

Cristoforo Buondelmonti left Florence for the Aegean in his mid-twenties in order to learn Greek. There, he wrote a geographical and archaeological description of Crete dedicated to Nicolò Niccoli, which may have originally contained a map. Five years later, in 1420, he produced his Liber insularum archipelagi, an encyclopaedia of the Aegean islands which matched maps of each island with a geographical description, some discussion of toponymy and classical history, and archaeological information..$^{42}$ Buondelmonti's Liber insularum was enormously popular in the late Quattro- and Cinquecento and according to Hilary Louise Turner, is known in sixty-four manuscript copies, only thirteen fewer than Marco Polo's travel account. ${ }^{43}$ It circulated only in manuscript and was not printed during the Renaissance. The book was particularly well received amongst Venetian readers, and in the late-fifteenth century, the Latin text was translated into Venetian vernacular in two copies. One of these Venetian dialect manuscripts of the Liber was even originally bound with a printed copy of Bartolomeo's Isolario, suggesting that at least one reader was interested in a very Venetian elaboration of the Aegean archipelago. ${ }^{44} \mathrm{~A}$ third, Latin copy of the Liber was probably produced in a Venetian context: Phyllis Williams Lehmann has

\footnotetext{
${ }^{42}$ See note 7 , above, for bibliography on Buondelmonti.

43 Turner, p. 13.

44 Venice, Biblioteca Nazionale Marciana, MS Ital. VI 19 (=6087). The other vernacular copy is Milan, Biblioteca Ambrosiana, MS Y. 72 sup. Neither contains maps. On the latter, see Veronica della Dora, 'Mapping a Holy Quasi-Island: Mount Athos in Early Renaissance Isolarii', Imago Mundi, 60.2 (2008), 139-65 (p. 162, n. 99).
} 
shown that Venetian scribes were probably responsible for correcting information about a bronze equestrian statue in Constantinople, recognizing that it depicted Theodosius and not Justinian. 45

Three Latin manuscripts of the Liber can be linked to specific Venetian owners. One copy now in Berlin was in the collection of Antonio Venier, a Venetian patrician prominently involved in the political life of the city and the Venetian terraferma at the end of the fifteenth century. Venier's volume is decorated with a wreath containing the initials 'A. V.', and contains Latin humanist poetry praising Venier written by friends to whom he lent the book to be consulted or possibly copied. ${ }^{46} \mathrm{~A}$ volume of the Liber now in the Biblioteca Civica in Padua contains an inscription recording that Taddeo Quirini - brother of the more famous humanist Nicolò on Crete - gave the book to Jacopo Zeno, the Venetian patrician bishop of Padua (1418-1481) ${ }^{47}$ Finally, Francesco Barbaro (1390-1454), one of the best known Venetian patrician humanists, owned a composite volume of geographical writing in which the Liber was included. ${ }^{48}$ This group of Venetian copies of Buondelmonti's Liber indicates the popularity of the text for elite humanist readers.

Copies of Venetian author Bartolomeo dalli Sonetti's Isolario were also often integrated into humanist book collections, mostly in printed copies, but as we shall see, in a handful of manuscript copies too. Of the individual print copies of Bartolomeo's Isolario that I have seen or seen reproduced, four are bound with wood board covered in brown calf leather, tooled blindly or in gold; in two instances, the clasps survive, and for two copies, the brown calf slipcase in which the book was preserved also survives. ${ }^{49}$ Of these copies, only one - that now in Modena's Biblioteca Estense - can be positively linked with

45 Phyllis Williams Lehmann, 'Theodosius or Justinian? A Renaissance Drawing of a Byzantine Rider', The Art Bulletin 41.1 (1959), 39-57 (p. 56).

${ }^{46}$ Berlin, Staatsbibliothek, MS Hamilton 108. See Die Lateinischen Handschriften der Sammlung Hamilton zu Berlin, ed. by Helmut Boese (Wiesbaden: Harrassowitz, 1966), pp. 58-60.

47 Padua, Biblioteca Civica, MS CM 289. See Barsanti, p. 89.

48 Marciana, MS Lat. X. 124 (= 3177). Barsanti, p. 89. See also Aubrey Diller, 'The Library of Francesco and Ermolao Barbaro', Italia Medioevale e Umanistica, 6 (1963), 253-62.

${ }^{49}$ Consulted in person: New York, Pierpont Morgan Library, Ch L 951; Cambridge, Trinity College, Wren Library, VI. 14. 10; Modena, Biblioteca Estense, Alfa E. 5. 15. Digital consultation: New Haven, Yale University, Beinecke Library, Taylor 24. 
an early owner, Giovanni Bembo, a Venetian colonial administrator in the Aegean in the 1520s. ${ }^{50}$ These small, gilt leather bindings, often with detailed abstract stamped designs, have been called characteristically 'humanistic binding'; indeed an Islamic interlaced stamped binding that Anthony Hobson reproduces, covering a manuscript sold by a Venetian stationer, is strikingly similar to that of the Pierpont Morgan Library copy of the Isolario (fig. 1). ${ }^{51}$ [INSERT FIG. 1 WITH CAPTION AT OR CLOSE TO HERE] Of these four Isolario copies, three are annotated: the Pierpont Morgan copy in the same hand in Latin and Greek; the Cambridge copy in the same hand in Latin and Italian; and Bembo's copy in his hand in Latin, Greek, and Italian (fig. 2). [INSERT FIG. 2 WITH CAPTION AT OR CLOSE TO HERE]

Readers' interest in the book as an aesthetic object is reflected in its Renaissance illustration. Ten copies of the Isolario that I have examined have coloured maps, all illustrated in a similar style of wash, with pale greens, blues, browns, and reds. ${ }^{52}$ Some, like a copy in the Paris Bibliothèque Nationale, are more accomplished than others. Whether the coloured washes were commissioned by the owners from artists or book illustration workshops, or were done by the owners, is unclear. Five copies contain coats-of-arms or segnate painted onto the first page of the book; only one of these has been identified, as that of the Donato, a Venetian patrician family. ${ }^{53}$ In two copies, one in the Biblioteca Marciana and another at Smith College, these painted false frontispiece decorations, with the family or owner's segnata in a roundel at the bottom of the page, were done by professional miniaturists or book illuminators (fig. 3). [INSERT FIG. 3 WITH CAPTION AT

\footnotetext{
50 On Bembo, see my monograph, Venice's Intimate Empire: Family Life and Scholarship in the Renaissance Mediterranean (Cornell University Press, forthcoming in 2018).

51 Anthony Hobson, Humanists and Bookbinders: The Origins and Diffusion of Humanistic Bookbinding, 1459-1559 (Cambridge: Cambridge University Press, 1988), pp. 58-59; an image of the stamped codex (Marciana, Gr. VIII, 7) appears on p. 67, fig. 54.

52 Consulted in person: Cambridge, Trinity, Wren Library, Grylls 3. 335, and VI. 14. 10; New York, Pierpont Morgan, Ch L 951, and Ch L 951a; Northampton, Mass., Smith College, Mortimer Rare Book Collection, B. 183; Modena, Biblioteca Estense, Alfa E. 5. 15; Venice, Marciana, Inc. 733. Digital consultation: Urbana-Champaign, University of Illinois, Inc. 852; Paris, Bibliothèque Nationale, Cartes et plans, GE DD 1989; Boston, Public Library, Q. H05. 128.

53 Paris, Bibliothèque Nationale, Cartes et plans, Res. Yd. 770 (not viewed).
} 
OR CLOSE TO HERE] They are elaborately decorated pages, with delicately shaded, grisaille borders which lend the page a feeling of having been engraved in marble, bordered with brightly coloured vegetation patterns and, in the Smith copy, with grottesche. ${ }^{54}$ This style of painted frontispiece was popular with humanist readers, and is especially associated with copies of vernacular poetry. ${ }^{55}$

The Isolario was indeed so desirable that once printed copies were no longer available, manuscript copies were produced for readers. Three manuscript copies of the Isolario survive, though probably more were produced in the early-sixteenth century. ${ }^{56}$ Although there are some slight spelling differences between these three copies, the hand and the colouring patterns are the same, which suggest that a single copyist or workshop was responsible for producing them. Whether they were commissioned by readers who were aware of the Isolario but could not find a printed copy for sale, or were produced speculatively by the workshop, is impossible to know; but in any case, it indicates both that the demand for the book very probably outpaced supply, and that the readers who sought these copies were wealthy enough to purchase high-quality manuscripts for their collections. Taken together with the manuscript drawings and annotations in printed copies, the manuscript codices also indicate the kind of permeability between manuscript

\footnotetext{
${ }^{54}$ Smith College, B. 183.

${ }^{55}$ Lilian Armstrong has argued that hand-painted frontispieces flourished in the incunable period in Venice: 'The Impact of Printing on Miniaturists in Venice after 1469', in Printing the Written Word: The Social History of Books, ed. by Sandra L. Hindman (Ithaca: Cornell University Press, 1991), pp. 174-204.

${ }_{56}$ London, National Maritime Museum, MS P/21 (consulted); Brussels, Bibliothèque royale de Belgique, Cartes et plans, 17847 (= 7379) (not consulted); Venice, Marciana, MS It. IX 188 (= 6286) (consulted on microfilm). The Brussels manuscript has been published by Wouter Bracke, 'Une note sur l'Isolario de Bartolomeo da li Sonetti dans le manuscrit de Bruxelles, BR, CP, 17874 (7379),' Imago Mundi, 53 (2001), 125-29. In Emmanuele Cicogna's notes in his copy of the Isolario, now in the collection of the Biblioteca Correr in Venice (Inc. f. 26), he references a manuscript codex in the Libreria Pesaro. In the catalogue of this private Venetian family library, the book is described as a 'codice manoscritto membranaceo del secolo XV, 40, con figure, legatura in vitello'. This is not the same manuscript as the Marciana copy, which Cicogna also inspected. Whether it is the codex now in London or Brussels, or a fourth manuscript which has remained in private hands, I have not been able to determine. See Marco Francesco Pesaro, Catalogo della libreria d'un illustre patrizio veneto (Padua: Stamperia del Seminario, 1805), p. 80, no. 1622.
} 
and printed media accepted by early modern readers, for whom the printed text was not considered fixed and manuscript could easily substitute for print. ${ }^{57}$ This latter attitude to manuscript is underlined by the workshop's extremely close adherence to the typeset of the printed copy, so well imitated that it is indeed impossible to date the hand. The only difference in treatment between the manuscript and printed copies is that the manuscript codices are not annotated; these codices may have been treated as semi-public works of art for display within a library or study, operating fluidly as both collectable objects and objects of scholarship.

\section{Annotating Antiquity in the Isolario}

How did Venetian collectors read and understand these geographical and epigraphical texts? As a case study, I have examined the marginalia in copies of Bartolomeo dalli Sonetti's Isolario, which was annotated by many of its Renaissance readers: and not to mine its classical information. Although printed and manuscript copies of Bartolomeo's Isolario were bound and illustrated for inclusion into elite book collections, the fifteenth- and sixteenth-century readers of the text were equally interested in Bartolomeo's claim to navigational expertise, and the social world of Venetian sailing from which he came.58 Perhaps the most common annotation is the underlining of either Bartolomeo's name, or the entire tercet in which he first introduces himself as an author: "bon venitian bartholomio | da li soneti ver compositore.' Often his name is written out in the margin of the page; Giovanni Bembo writes in the Estense copy, 'Bartholomio da li Soneti Venetiano

\footnotetext{
${ }^{57}$ On the fluidity and co-existence of manuscript and print cultures in Renaissance Italy, see Brian Richardson, Manuscript Culture in Renaissance Italy (Cambridge: Cambridge University Press, 2009), pp. 1-14; and Michael D. Reeve, 'Manuscripts Copied from Printed Books', in Manuscripts in the Fifty Years after the Invention of Printing, ed. by Joseph B. Trapp (London: Warburg Institute, 1983), pp. 12-20. For Venice, see Marino Zorzi, 'Dal manoscritto al libro', in Storia di Venezia dalle origini alla caduta della Serenissima. 4: Il Rinascimento. Politica e cultura, ed. by Alberto Tenenti and Ugo Tucci (Rome: Istituto dell'Enciclopedia Italiana, 1996), pp. 839-52; Helena Szépe, 'Venetian Miniaturists in the Era of Print', in The Books of Venice. Il Libro Veneziano, ed. by Lisa Pon and Craig Kallendorf (Venice: Biblioteca Nazionale Marciana, 1986), pp. 31-60.

${ }^{58}$ Details of the copies, by library holding, as in notes 52 and 56 above; references provided only for copies not previously discussed or to avoid ambiguity.
} 
Auctor', in large roman capitals. Readers also demonstrate an interest in Bartolomeo's autobiographical writing in the last sonnet of the introduction: for instance, in the Florence copy, the second line of the pair, 'Per aprobar questa opereta fata | per me bartholomeo da li sonetti' is underlined, as it is in several other copies. The readers of the Florence and British Library copies also underlined all of the Venetian patrician families with whom Bartolomeo claims he sailed.59 In the copy now in the Correr, Bartolomeo's description of himself as 'oficiale e poi patrone in nave' is underlined, along with the family names. In copies in the Pierpont Morgan collection and in Madrid, this second sonnet is given a title: for the first, 'Soneto de chi a fato l'opera - et i[n] che modo', and for the latter, 'Soneto in $\mathrm{qu}[\mathrm{al}]$ modo ha facto le insule'.60 The question of who made the Isolario - resolved by seeking his name, profession, the social curriculum vitae of Venetian trade expeditions was an important one to readers of the book, as was Bartolomeo's method of, and authority to, create it. Again in the Correr copy, the lines in which Bartolomeo writes of wandering the islands and marking them on his maritime charts are underlined. In Giovanni Bembo's copy, he writes next to this sonnet, 'Auctoris navigationis', commenting upon the authority lent to Bartolomeo as a poet by his experience sailing in the Aegean. The reader of the Trinity College copy writes next to the same sonnet, ' 15 viagii con Gallere, Bartholommeo fatto', as well as 'Capitani de gallere sue'. Bartolomeo's experience of the Mediterranean as a navigator was itself collectable: it was his transformation of that knowledge into humanist encyclopaedic form that made the book an important object for elite readers.

The copy now in Florence illustrates this phenomenon particularly well. It contains many fine ink sketches alongside the coloured wash on the maps, and is full of beautifully drawn ships, both galleys and round merchant ships, often portrayed as though cutting quickly through the waves (fig. 4). [INSERT FIG. 4 WITH CAPTION AT OR CLOSE TO HERE] These ships are Venetian, and dateable to the second half of the fifteenth century; more intriguingly, the perspective from which many of them were drawn is strikingly similar to that of the ships in the background of Carpaccio's St. Ursula cycle, particularly The Return of the Ambassadors and The Meeting of St. Ursula and the Prince, which were painted for the

59 Florence, Biblioteca Nazionale Centrale, Magl. F. 6. 6; London, British Library, IA. 23056. ${ }^{60}$ Pierpont Morgan, Ch L 951; Madrid, Biblioteca Nacional de España, INC 1261. 
Scuola di Sant'Orsola in Venice in 1497-1498. ${ }^{61}$ The copy also contains two opening pages of calendrical and astrological material: on the first page, two wheels are shown, one for determining the date of Easter and beginning in 1512, the other beginning in 1508; on the second page, there is a drawing of numbered computus manualis diagrams, explaining how to use the hand to calculate calendrical information, again beginning in 1512. Only the first map has a toponym annotated, in a different (humanist) hand from the instructions for using the calendrical wheels and hand diagrams; this latter hand is a Venetian mercantesca, and the text in Venetian dialect. The owner and illustrator of this copy were very likely contemporary Venetians, probably working with the book in the first decade of the sixteenth century; one of them could have been affiliated with Scuola di Sant'Orsola, where he would have seen Carpaccio's paintings. The book was perhaps purchased by a humanist reader, maybe affiliated both with the world of merchant-mariner textual production and with humanist scholarship, a professional spectrum which reflects that of Bartolomeo dalli Sonetti himself. In its inclusion of Venetian merchant-mariner texts like the calendrical wheels and hand diagrams alongside the detailed drawings of ships and colouring, the Florence copy speaks of a reader who considered the book's association with Venetian navigation to be worthy of being richly illustrated and accented, to be essential to its aesthetic worth as a collectable object. ${ }^{62}$

Bartolomeo's construction of his expertise as a navigator, his experience of the Mediterranean, contemporary readers' interest in that information, and even one owner's inclusion of technical diagrams related to the navigational miscellany tradition, all indicate

61 I am very grateful to Lilia Campana of the Institute for Nautical Archaeology at Texas A\&M University, who identified and dated these ships, and suggested their similarity to Carpaccio's paintings. (Personal correspondence, 11 February 2013). The St. Ursula cycle now hangs in the Gallerie dell'Accademia, Venice. See Patricia Fortini-Brown, Venetian Narrative Painting in the Age of Carpaccio (New Haven: Yale University Press, 1988), pp. 56-60, 193-96.

62 This illustrated book suggests another important link with Venetian merchant-mariner texts, much like Bartolomeo's own use of portolano language and graphic symbols. Manuscripts such as the Michael of Rhodes codex and the elite manuscript collection of portolan charts now in the British Library, the so-called Cornaro Atlas (MS Egerton 73) point to suggestive connections between the more 'technical' texts of merchant-mariner writing and mapping, and the 'literary' production of Bartolomeo dalli Sonetti. 
that the Isolario seems to have been collectable as evidence of a direct Venetian encounter with the physical islands and seascape of the Aegean. However, as Bartolomeo himself recognized in borrowing form and some content from Buondelmonti's Liber insularum, his Isolario would be purchased by elite book collectors, and read and annotated by wealthy owners who would scribble Latin and Greek in its margins. Bartolomeo's Isolario gives evidence of the ways in which the physical world of Venetian navigation was translated into verse and image, to become collectable by elite readers who would experience that world from the confines of the study.

Readers' impressions of the books of islands equally reveal how effectively Bartolomeo dalli Sonetti and Cristoforo Buondelmonti made over the Mediterranean as a humanist space. As mentioned briefly above, Antonio Venier, the Venetian patrician humanist who held a number of political offices in the Venetian terraferma, owned a copy of Buondelmonti's Liber insularum, and lent it out to his friends to read or possibly to have copied for themselves. ${ }^{63}$ The manuscript was probably copied from a Cyriacana collection, as it also includes drawings of Mercury and of an elephant that can be traced to Cyriac's Commentaria, and a poem about the fall of Constantinople by Gianno Pannonnio which is attested in two other Cyriacana collections. ${ }^{64} \mathrm{His}$ friends gratefully wrote short Latin poems to thank Venier for his generosity, poems which also serve as unique evidence for the kinds of reading to which Buondelmonti's book was subjected. Their most common conceit is that by lending them the Liber, Venier allowed them to travel through the Cyclades, the Sporades, Crete, and other islands without having to face the danger of sea travel. Ludovico Cendrata articulates this idea by writing: 'I might traverse these famous Cyclades islands at seventy-nine years old, without fear of attack or the danger of the sea.' ${ }^{65}$

\footnotetext{
63 Berlin, Staatsbibliothek, MS Hamilton 108. Ludovico Cendrata, one of Venier's friends to whom he lent the book, wrote an inscription of thanks in the manuscript, dated from Verona, 1481, when Venier was serving as the city's podestà. See Benjamin Kohl, Andrea Mozzato, and Monique O'Connell, 'The Rulers of Venice, 1332-1524', record 52705 (rulersofvenice.org).

64 Barsanti discusses the poem, p. 90. It is also found in: Rome, Biblioteca Casanatense, MS 106; Treviso, Biblioteca Comunale, MS 323.

$65^{\prime}[\mathrm{U}] \mathrm{t}$ uno ferme impetu novem et septuaginta absque maris periculo Cyclades percurrerem clara insularum notitia': Boese, p. 60.
} 
Marcantonio Averoldi writes that 'Indeed, you shall not see more of the earth and sea from a fast ship through the Cyclades in a month, than that which is depicted in this short work.' ${ }^{66}$ Augustinus Capellus of Verona writes in his rhyming poem: 'To have traversed the sea free from danger | with nothing undertaken and no fear: | I owe all this to you, Venier, | as you have shared this little book with me.' ${ }^{67}$ The humanist Bernardo Bembo, probably best known for his Platonic love for Ginevra de' Benci, and for restoring Dante's tomb whilst serving as a Venetian governor in Ravenna, wrote two lines addressed to future readers of Venier's book: 'You desire to traverse lands and seas: | That, reader, which you seek in vain: seek [here].' ${ }^{\prime 6}$ In these poems and prose notes, Venier's friends articulate the privilege of encountering the Mediterranean through the maps and descriptions of Buondelmonti's Liber. Buondelmonti's topological and archaeological writing on the islands is a substitute for witnessing it first-hand: not only is Mediterranean space a place of humanist inquiry, as in Cyriac's Commentaria, but it is something to be consumed, read, and collected within the humanist study. These readers were all associated with Venetian terraferma humanism and governance: Cendrata was a consigliere and public orator in Verona; Averoldi, a doctor of liberal arts in Brescia; even Bernardo Bembo and Venier, both Venetian patricians, were politically active on the mainland, Bembo as podestà of Ravenna and Verona, and Venier in Brescia and Padua. ${ }^{69}$ These men were offered an alternative, textual encounter with the Mediterranean through Buondelmonti's Liber, from their terraferma studies in Padua, Verona, and Brescia.

A similar picture emerges from comparison with contemporary readers' annotations to Bartolomeo's Isolario. Aside from Bartolomeo's own identity, as noted

66 'Nanque orbem et celeri quas per mare mense carina Cyclades haud videas, hoc breve pingit opus': ibid., p. 58.

67 'Nullis sumptibus, et timore nullo, | Percurri, vacuus maris periclo: | Hoc totum tibi debeo, Veneri, | Dum me hoc particem facis libello': ibid., p. 59.

68 'Metiri quicunque cupis terrasque fretumque | Haec, frustra lector quid petis illa, pete': ibid., p. 59. Bernardo and Giovanni Bembo (see note 50 above) were both members of the large Bembo clan in Venice, but were not from the same branch of the family.

${ }^{69}$ See the entries in the Dizionario Biografico degli Italiani: Marco Palma, 'Cendrata, Ludovico', vol. 23 (1979), and Angelo Ventura and Marco Pecoraro, 'Bembo, Bernardo', vol. 8 (1966), consulted online: http://www.treccani.it/biografico/index.html. For Capellus and Averoldi, information from their own inscriptions. 
above, readers were particularly interested in Bartolomeo's sources and in the classical information he provided: primarily pairs of classical and modern toponyms, and mythological figures. Next to the passage in the introductory poem in which he lists the authors he has made resound, readers often underline the names or copy them into the margin. Bartolomeo himself vividly animates a series of classical authors in the text of his introductory poem. He begins with Virgil, as imagined in the opening canto of Dante's Inferno: 'Al primo e quel che ove il sol tace sede | nel gran diserto'. He goes on to 'hear' Dionysius Periegetes, 'che scripse cantando | de situ orbis cum tal melodia | che al ciel va $\mathrm{a}[\mathrm{n}]$ chor sua fama arinsonando'; as well as Pomponius Mela, 'che un orpheo p[ro] par cantando el sia'; and finally Strabo, 'reciting' the history of Sparta. ${ }^{70}$ Each of the authors is introduced with auditory language, especially focused on singing and reciting. The orality of Bartolomeo's references suggest that he hears them in the present tense, through their prose; and it is through his verse in the Isolario that their voices can again resound in print. Knowledge about the Mediterranean world was not produced simply by reading and compiling classical texts, then, but through an imaginary oral exchange with classical authors.

Readers were also particularly interested in the pairs of classical and modern toponyms Bartolomeo references in his sonnets. Nearly all of the annotated copies that I have seen or seen reproduced have toponymy either underlined in the text, written in the margin, or copied from the sonnets onto the maps. For example, in a copy now in the Bodleian, a Frater Modestus of Bari transferred the ancient toponymy of the sonnet about Tinos into its map. The lines from the sonnet which refer to etymology read, 'Tine questa si chiama e si chiamo | da aristotile greco prima idrosa | e demostene gli disse ophiosa', and Modestus has written 'Tine' inside the borders of the island and 'idrosa' and 'ephyosa' next to it. Next to the sonnets on Sdiles, he has extracted all of the ancient toponymy into the margin: ortigia, asteria, cintia, delos, zinetto, pirpile, lagia, certa. In the first lines of his poem on Sancta Erini, Bartolomeo mentions two smaller islands close to its shores: 'Verso la par te dove il sol tramonta | da nansio e vinti miglia apolegassa.' Modestus drew these smaller islands onto the map, and labelled them 'apolega' and 'na[n]sio'. He also labelled

${ }^{70}$ Isolario, p. $1 \mathrm{v}$. 
the diagrammatic representations of churches and castles on the islands, again copying the information from sonnet to map. ${ }^{71}$ The annotators of the Smith College copy and the Boston Public Library copy, as well as Giovanni Bembo in the Estense copy, transferred Bartolomeo's long list of city names in his sonnets on Crete onto the bi-folio map. Bembo also copied the sonnets' ancient toponyms onto the margins of the page. The readers of the Isolario seemed to have extracted toponymic information from the text of the sonnets, to place them in list form in the marginal space, or to copy them onto maps.

The names of mythological and classical figures, and the landscapes associated with them, were treated similarly by annotators. One figure that caught readers' attention was Homer. In the first lines of Bartolomeo's sonnet on Sciro, he writes: 'Se dice in questa eser sepulto homero | il gran poeta degno singulare.' Bembo as well as the annotator of the Marciana copy found this important, and wrote 'homerus poeta' and 'homero', respectively. (Cyriac, too, was taken with the idea of Homer's tomb: in a letter to the Genoese humanist Andreolo Guistiniani from Chios in 1446, he writes how he made 'a little excavation' on the island to try to find the tomb, and despite finding nothing still wrote that is was 'a joy and a pleasure to gaze upon the place that the greatest of poets [...] chose as the locale worthy of and most appropriate to his profound vision'..) ${ }^{72}$ The Marciana annotator was interested in other classical and mythological figures: he wrote 'valerio r[e]gno' in the margin of the sonnet on Samo, in which Bartolomeo writes of 'Valerio regno qui crudel a ognuno [...]'. In the first lines of the sonnet on Nicaria, Bartolomeo relates the myth of Icarus and Dedalus, in which Icarus tumbles into the sea surrounding the island; the annotator has summarized this in the margin, as 'icaro fil[ius] de dedalo'. The Trinity College annotator combined toponyms, mythological figures, and notable features of the islands in lists in the margins: next to the sonnet on 'Citharea', he writes 'Venus | Diana | Dea | Paris et Elena | Montuosa | habitata | insula prima'. These lists represent the units of information most valued by the reader, and the kind of information they extracted is consistent across the annotated copies. The maps in the Isolario became thematic ones, a jumbled catalogue of historical

71 Oxford, Bodleian Library, Auct. Q. 5. 29.

72 Cyriac, Later Travels, pp. 288-91: 'Sed summa hylaritate placuerat inspectasse loca, quae maximus ille vatum et rerum omnigenum peritissimus homo altae suae meditationi digna peridoneaque [diaprepestata] delegerat in insula scilicet singulari.' 
toponyms from Aristotle and Pliny to the Venetian names of the present. Venus and Diana were still as much present for these readers on the island of Cythera as its mountainous physical landscape. The readers of the Isolario were not simply interested in studying the past; they were interested in studying the past as presence. For Venetian humanist readers, the names and landscapes of antiquity belonged to several different historical times and spaces simultaneously: this was Venus's Aegean, Homer's, Aristotle's, Pliny's, as well as Bartolomeo's and the Venetians'. The past was both used to create the Venetian present, and was a living presence itself.

\section{A composite imperial story}

For Renaissance Venetians, a literary culture about empire articulated the nature of colonial space in the Mediterranean, and provided a classical and contemporary history for that space. These texts were not materially powerful like the administrative, judicial, and governmental documents that were deployed across the stato da mar. And yet the Renaissance Venetian humanist texts of empire provided a shared literary and intellectual culture for an often geographically dispersed political class. More importantly, they provided a set of ideas, images, and expectations of the empire they were governing, and of their own political and social roles within that empire.

The geographical and epigraphical literary culture they accumulated about the Venetian Mediterranean articulated both the nature of the space of the maritime state, and provided a layered sense of history for Venetian readers at home. Cyriac's composite recording of the scattered and incomplete remains of classical antiquity became a more truthful way to record the fragmentariness of the Aegean past, at the same time capturing its persistence into the present. The island encyclopaedias - particularly Bartolomeo's, steeped as it was in the language and experience of Venetian mariners - posited a Venetian Mediterranean of composite spaces linked together through navigational practice. In the isolarii, the Venetian Mediterranean was presented as a space of composite temporalities, in which one could meet the ships of Venetian padroni as easily as find Homer's tomb. In their readers' annotations, we can see that temporality itself became

blended, layering contemporary Venetian history with antiquity so that the antique past persisted into the present. This fifteenth-century corpus of composite geographical and 
epigraphical literature about the Aegean island world pieced together the fragmented and contingent spaces of sovereignty in the stato da mar for their Venetian readers at home in the metropole. 